\title{
Formulation of Effective Microbial Consortium and Its Application for Industrial Wastewater Treatment
}

\author{
Mahilarasi A', Jaianand Kannaiyan², Rameshkumar ${ }^{3}$, Balaji Paulraj ${ }^{2}$, Veeramanikandan Veeramani1* \\ ${ }^{1}$ PG \& Research Centre in Microbiology, MGR College, Dr. MGR Nagar, Hosur 635109, Tamil Nadu, India
}

${ }^{2}$ PG \& Research Centre in Biotechnology, MGR College, Dr. MGR Nagar, Hosur 635109, Tamil Nadu, India

3PG and Research Department of Zoology, Vivekananda College, Madurai 625214, Tamilnadu, India

\begin{abstract}
The present study was conducted for auto mobile industry, food industry and pharmaceutical industries waste water treatment using effective microbial consortium. The effective microorganisms like Acinetobacter pittii, Escherichia coli, Fictibacillus nanhaiensis, Lysinibacillus xylanilyticus and Planococcus maritimus were isolated from respective sources. The microbial consortium was formulated using molasses as medium at $\mathrm{pH}$ 3.8 and incubated at $37^{\circ} \mathrm{C}$ for 3 days. The results showed that the formulated consortium was efficient for industrial waste water treatment and thereby it reduced the environmental impact.
\end{abstract}

Keywords: Bio-remediation, Microbial consortium, Industrial waste water, Heavy metals

Article Info: Received 13 June 2019; $\quad$ Review Completed 22 July 2019; $\quad$ Accepted 26 July 2019; Available online 15 August 2019

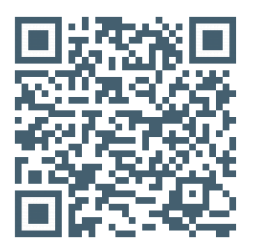

Cite this article as:

Mahilarasi A, Jaianand K, Rameshkumar K, Balaji P, Veeramanikandan V, Formulation of Effective Microbial Consortium and Its Application for Industrial Wastewater Treatment, Journal of Drug Delivery and Therapeutics. 2019; 9(4-s):111117 http://dx.doi.org/10.22270/jddt.v9i4-s.3260

Dr. Veeramanikandan Veeramani, Assistant Professor, Research Centre in Microbiology, MGR College, Dr. M.G.R. Nagar, Hosur- 635 109, Tamilnadu, India

\section{INTRODUCTION}

Microorganisms such as bacteria, algae, fungi and yeast etc. have evolved to adapt the changing environmental conditions and have developed various molecular and biochemical processes to overcome adverse environmental conditions. Some bacteria have developed the tolerance to environmental stress such as heavy metals and toxic chemicals. Reports suggest the role of several functional groups present on the bacterial cell wall which can play important role in the metal ions sorption from the environment 1 . The various other mechanisms involves energy dependent efflux of metal ${ }^{2}$, precipitation of the metal as insoluble salts ${ }^{3}$, alteration in the permeability of membrane ${ }^{4}$, production of chelating agents ${ }^{5}$ and biochemical transformation of metal ions ${ }^{6}$. Even though the bacteria have developed resistance to the environmental pollutants particularly heavy metals, there is a lack of understanding on the molecular mechanism of metal detoxification and application for bioremediation.

The remediation of heavy metal contaminated soil and water have been a major challenge for a long time ${ }^{7}$. The traditional physiochemical methods such as electrochemical treatment, ion-exchange, precipitation, reverse osmosis, evaporation and oxidation/reduction for heavy metal removal from waste streams are expensive, not ecofriendly and inefficient for metal removal ${ }^{8}$. In recent past biosorption has emerged as an alternative to these traditional methods with several advantages such as technically easy, potential for regeneration and sludge free operations ${ }^{9}$. In addition, it is an ecofriendly and low cost method for remediating heavy metals ${ }^{10-11}$. At higher concentration heavy metals are potent toxicants that interfere with the normal biochemical reactions of the human body. The release of metals into the environment also causes environmental pollution problems as they are non-biodegradable and accumulate in the living system $^{7}$. Exploiting taxonomically diverse microbes particularly bacteria in remediating heavy metals and restoration of polluted environment have been a major focus of research in recent times. However, it is important to ensure that appropriate treatment standards are selected to meet local conditions, and alternative innovative technologies for treating wastewater are considered. This present study revealed that the bacterial isolates were able to tolerate different concentration of heavy metals recovered from the different industrial wastes and the isolates were resistant to 
the different antibiotics. Thus the present study defend that heavy metal resistance leads to antibiotic resistance, also these bacterial isolates can be used for the bioremediation of heavy metals.

\section{MATERIALS AND METHODS}

\section{Sample collection}

A total of three different industrial waste water samples were collected from various industries such as auto mobile industry, food industry and pharmaceutical industries metal dumping site located in District Krishnagiri, Hosur. Effluent samples were collected in dry, sterile polypropylene containers and transported immediately to Microbiology Research Laboratory at the Department of Microbiology, MGR College Hosur. These containers were maintained at $4^{\circ} \mathrm{C}$ to ensure the minimal biological activity. Processing of samples for isolation of bacteria was carried out within $3 \mathrm{~h}$ of sample collection.

\section{Biochemical Characterisation and Degradation Potency}

The bacterial species were isolated from the collected water samples, biochemical tests were performed in order to establish the identities of different isolates and heavy metal resistant bacterium obtained and screened with selective mineral salt medium (sMSM) as per the previous research methodology12,13. All the potential isolates and strains were screened according to non- pathogenicity for human/animals and their higher biodegradable efficiency and particular strains were selected in consortium formulation. The growth of the isolates was examined under highest concentration (200 to $2000 \mathrm{ppm}$ ) at different days of incubation and checked the viability and growth after 10,20 and 30 days.

\section{Formulation and Analysis}

Microbial-based consortium containing both a liquid (vegetative state) and dry (spore and microencapsulated vegetative state) formulation was designed and final formulated consort were tested under auto mobile industry, food industry and pharmaceutical industries waste water under environment climatic conditions, humidity and temperature to confirm the successful delivery. The microbial consortium was formulated using molasses as medium at $\mathrm{pH}$ 3.8 and incubated at $37^{\circ} \mathrm{C}$ for 3 days. The parameters were analyzed as per APHA standard methods ${ }^{14}$ for the examination of water and waste water degradation level 15 of different group of compounds: (A) Organics Compounds - A determination of the concentration of carbon-based (i.e., organic) compounds aimed at establishing the relative "strength" of wastewater were analyzed for Biochemical Oxygen Demand (BOD) and Chemical Oxygen Demand (COD), (B) Solids - A measurement of the concentration of particulate solids that can dissolve or suspend in wastewater (i.e., inorganic) were analyzed for Total Solids (TS), Total Suspended Solids (TSS), Total Dissolved Solids (TDS), Total Volatile Solids (TVS), and Total Fixed Solids (TFS), (C) Other parameter such as $\mathrm{pH}$, Sulphate, Chloride, and heavy metal analysis for Copper, Nickel, Zinc, Arsenic, Lead, Cadmium, Selenium, Mercury and Hexavalent chromium were analyzed on day $0,10,20$ and 30 after microbial consortium treatment on auto mobile industry, food industry and pharmaceutical industries waste water.

\section{Molecular Characterization:}

A colony PCR method was used for amplification of $16 \mathrm{~S}$ rDNA. Bacterial 16S rDNA was amplified from the extracted genomic DNA by using the universal bacterial 16S rDNA primers $8 \mathrm{~F}$ forward primer (5'AGAGTTTGATCCTGGCTCAG3') and 1541R reverse primer (5'AAGGAGGTGATCCAGCCGCA3'). The PCR product was sequenced using the primers. Sequencing reactions were performed using a ABI PRISM BigDyeTM Terminator Cycle Sequencing Kits with AmpliTaq DNA polymerase (FS enzyme) (Applied Biosystems) and consists of an initial $95^{\circ} \mathrm{C}$ denaturation for $2 \mathrm{~min}$ followed by 25 cycles of $95^{\circ} \mathrm{C}$ for $30 \mathrm{sec}, 55^{\circ} \mathrm{C}$ for $30 \mathrm{sec}, 72^{\circ} \mathrm{C}$ for $2 \mathrm{~min}$, followed by a final extension at $72^{\circ} \mathrm{C}$ for $10 \mathrm{~min}$. Single-pass sequencing was performed on each template using below 16s rRNA universal primers. The samples were resuspended in distilled water and subjected to ectrophoresis in an ABI 3730xl sequencer (Applied Biosystems).

Sequences were matched with previously published bacterial 16S rDNA sequences in the National Centre for Biotechnology Information (NCBI) databases using Basic local alignment search tool using nucleotide query (BLASTN) ${ }^{16}$. Based on the scoring index, the program MUSCLE 3.7 was used for multiple alignments of sequences ${ }^{17}$. The resulting aligned sequences were cured using the program Gblocks $0.91 \mathrm{~b}$. This Gblocks eliminates poorly aligned positions and divergent regions ${ }^{18}$. Finally, the program PhyML 3.0 aLRT was used for phylogeny analysis and HKY85 as substitution model. PhyML was shown to be atleast as accurate as other existing phylogeny programs using simulated data, while being one order of magnitude faster. The program Tree Dyn 198.3 was used for tree rendering 19 .

\section{RESULTS AND DISCUSSION}

A total of 27 isolates were collected from metal dumping sites from Hosur region, and nine isolates were screened after heavy metal resistance experiment. The isolates were further identified based on morphological characteristics such as size, colour and texture. The microscopic examination of these isolates revealed that out of 9 isolates, 3 were gram-positive cocci, 6 were gram-negative bacilli. Finally, five best isolates are picked from samples which were tolerant to high concentrations of the heavy metals under study (C1, D1, D2, $\mathrm{E} 1$, and E2). All the five isolates were able to grow at the highest concentrations at 2000ppm of $\mathrm{Al}\left(\mathrm{No}_{3}\right)_{3} 18 \mathrm{~mm}, \mathrm{CaCl}_{2}$ $19 \mathrm{~mm}, \mathrm{CoCl}_{2} 25 \mathrm{~mm}, \mathrm{~K}_{2} \mathrm{Cr}_{2} \mathrm{O}_{7} 26 \mathrm{~mm}, \mathrm{HgCl}_{2} 15 \mathrm{~mm}$, NiSo 4 $20 \mathrm{~mm}, \mathrm{ZnSo}_{4} 25 \mathrm{~mm}$ and $\mathrm{CuSO}_{4} 26 \mathrm{~mm}$. The bacterial isolates were tested for their sensitivity to 19 different commonly used antibiotics. Almost all the bacterial isolates were resistant to most of the antibiotics. In the antibiotic cultural sensitivity assay, five isolates were found resistant to four or more different groups of antibiotics (Table 1). Such isolates were regarded as multidrug resistant. This number further increased when the intermediate resistance was also accounted for among resistant strains. 
Table 1. Antibiotic susceptibility of heavy metal resistant bacteria isolates

\begin{tabular}{|l|c|c|c|c|c|c|c|c|c|}
\hline Antibiotic disc name & A1 & A2 & B1 & B2 & C1 & D1 & D2 & E1 & E2 \\
\hline Amoxicillin [AC] $10 \mathrm{mg}$ & -- & $12(\mathrm{R})$ & -- & -- & -- & $<10(\mathrm{R})$ & $<10(\mathrm{R})$ & - & -- \\
\hline Ampicillin $[\mathrm{A}] 10 \mathrm{mg}$ & $<10(\mathrm{R})$ & $10(\mathrm{R})$ & -- & $<10(\mathrm{R})$ & -- & $<10(\mathrm{R})$ & $<10(\mathrm{R})$ & $<10(\mathrm{R})$ & -- \\
\hline Ampicillin/ sulbactum [AS] $10 \mathrm{mg}$ & -- & $14(\mathrm{I})$ & -- & $10(\mathrm{R})$ & -- & $<10(\mathrm{R})$ & $10(\mathrm{R})$ & -- & - \\
\hline Bacitracin [B] 30 mg & -- & - & $<10(\mathrm{R})$ & -- & $<10(\mathrm{R})$ & -- & -- & -- & $<10(\mathrm{R})$ \\
\hline Cefepime [CPM] 30 mg & -- & $21(\mathrm{R})$ & - & $18(\mathrm{I})$ & -- & $14(\mathrm{R})$ & $12(\mathrm{R})$ & -- & -- \\
\hline $\begin{array}{l}\text { Cefixime/ clavulanic acid [CMC] } \\
\text { 5/100 mg }\end{array}$ & -- & $26(\mathrm{R})$ & -- & $14(\mathrm{R})$ & -- & $10(\mathrm{R})$ & $16(\mathrm{R})$ & -- & -- \\
\hline Chloramphenicol [C] 30 mg & $10(\mathrm{R})$ & $14(\mathrm{I})$ & -- & $17(\mathrm{R})$ & -- & $17(\mathrm{R})$ & $11(\mathrm{R})$ & $24(\mathrm{R})$ & -- \\
\hline Ciftazidine [CA] 30 mg & -- & $11(\mathrm{R})$ & -- & $11(\mathrm{R})$ & -- & $<10(\mathrm{R})$ & $11(\mathrm{R})$ & -- & -- \\
\hline Erythromycin [E] 15 mg & $<10(\mathrm{R})$ & -- & $<10(\mathrm{R})$ & -- & $<10(\mathrm{R})$ & -- & -- & $<10(\mathrm{R})$ & $<10(\mathrm{R})$ \\
\hline Methicillin [M] 30 mg & -- & -- & $<10(\mathrm{R})$ & -- & $<10(\mathrm{R})$ & -- & -- & -- & $<10(\mathrm{R})$ \\
\hline Novobiocin [NV] 30 mg & -- & -- & $<10(\mathrm{R})$ & -- & $<10(\mathrm{R})$ & -- & -- & -- & $<10(\mathrm{R})$ \\
\hline Penicillin-G [P] 30 mg & -- & -- & $<10(\mathrm{R})$ & -- & $<10(\mathrm{R})$ & -- & -- & -- & $<10(\mathrm{R})$ \\
\hline Piperacillin [PC] 100mg & -- & $14(\mathrm{R})$ & -- & $11(\mathrm{R})$ & -- & $<10(\mathrm{R})$ & $10(\mathrm{R})$ & -- & -- \\
\hline Tobramycin [TOB] 10 mg & -- & $10(\mathrm{R})$ & -- & -- & -- & $10(\mathrm{R})$ & $24(\mathrm{R})$ & -- & -- \\
\hline
\end{tabular}

Note: All numerical values of diameter in $\mathrm{mm}$ and represents Resistant (R), Sensitive (S), Intermediate (I)

From this study, it is determined that native bacteria present in the wastewater have the property of heavy metal resistance and ability to accumulate heavy metal environment through the process of biosorption. Acinetobacter pittii, Escherichia coli, Fictibacillus nanhaiensis, Lysinibacillus xylanilyticus and Planococcus maritimus are efficient in the removal of heavy metals $(\mathrm{Cr}, \mathrm{Cd}, \mathrm{Cu}, \mathrm{Zn}, \mathrm{Pb}, \mathrm{Ni}$ ) from the environment. Further, results obtained for analysis of the metal binding protein and alkaline phosphatase suggests that these native bacteria are potential bio tools for bioremediation of metal pollutants in the environment. The microbial consortium was clustered into two groups: gramnegative bacterium Acinetobacter pittii and Escherichia coli were a grouped into first consortium formulation and the gram-positive bacterium such as Fictibacillus nanhaiensis, Lysinibacillus xylanilyticus and Planococcus maritimus were formulated in the second group consortium.

Both first group and second group microbial consortium for the treatment of automobile industry wastewater, food industrial wastewater and pharmaceutical industrial wastewater was dramatically decreased from the raw water values respectively. The proportion of reduction of the observed parameters after five days of incubation was tabulated in Table 2. Trial samples were introverted at an interval of every 24 hours, and all the physico-chemical factors were documented for all the different combinations. A pattern of reduction in factors was detected in all the microbial consortium combinations, which indicated a continuous reduction from the first day and a maximum reduction was detected at the end of five days of incubation, and the factors are given in Table 2. There is no conversion in the $\mathrm{pH}$ in the management trials, and this factor is minor meanwhile it persisted well under the permissible limits. A maximum of the group a consortium reduction in the Chemical Oxygen Demand was observed in the automobile industrial wastewater. The ability of microbial consortium to reduce Chemical Oxygen Demand increased from day 1 to 5 Physico-chemical categorization of untreated discharge and auxiliary escalation in this Chemical Oxygen Demand was observed after five days. The rise in the Chemical Oxygen
Demand value on the late days might be the indication of incongruous mixing ratio among microbial consortium and organic resources. About both of the microbial consortium group A and microbial consortium group B passed more than $50 \%$ reduction in Chemical Oxygen Demand after five days of incubation.

The entire organic content removal in case of collective electrochemical and activated carbon absorption for wastewater management was about $59 \%$, but in the current study microbial consortium was capable of decreasing the organic content of up to $69.4 \%$. A maximum reduction of TDS was observed for the first group microbial consortium. Moreover, both consortiums of microbes groups were found to be capable in the reduction of TDS than other parameters. There is also a remarkable reduction in the turbidity, which showed that there is a clear reduction in the percentage of the suspended solids in this set. All groups of microbial consortium are almost able to efficiently decolourize the effluent efficiently, the cause for the consortium that is not so effective might be for a reason that of the incompatible nature of the organisms used in the consortium or because of the action the secondary metabolites secreted by one on the other.

Similarly, both groups consortium was actively reduced the heavy metal components efficiently. The percentage of heavy metal concentration after microbial consortium treatment in auto mobile industrial waste water was tabulated in table 3 . Consistently, the percentage of heavy metal concentration after microbial consortium treatment in food industrial waste water was tabulated in table 4 . Likewise, the percentage of heavy metal concentration after microbial consortium treatment in pharmaceutical waste water was tabulated in table 5. To conclude that the present study revealed that the bacterial isolates were able to tolerate the discussed different concentration of heavy metals recovered from the contaminated sites. Furthermore, the isolates were resistant to the different antibiotics which were used against the isolates. Thus, the present study justifies that heavy metal resistance leads to antibiotic resistance, also these bacterial isolates can be used for the bioremediation of heavy metals. 
Table 2. Proportion of reduction of the observed parameters after five days of incubation

\begin{tabular}{|c|c|c|c|c|c|c|c|c|c|c|}
\hline \multirow[t]{3}{*}{ Parameters } & \multirow{3}{*}{$\begin{array}{l}\text { Pollution } \\
\text { Control } \\
\text { Norms }\end{array}$} & \multicolumn{3}{|c|}{ Auto Mobile Industrial Waste Water } & \multicolumn{3}{|c|}{ Food Industrial Waste Water } & \multicolumn{3}{|c|}{ Pharmaceutical Waste Water } \\
\hline & & \multirow{2}{*}{$\begin{array}{c}\begin{array}{c}\text { Before } \\
\text { Treatment }\end{array} \\
\text { Initial } \\
\text { values }\end{array}$} & \multicolumn{2}{|c|}{$\begin{array}{c}\text { Microbial Consortium } \\
\text { Treatment }\end{array}$} & \multirow{2}{*}{$\begin{array}{c}\begin{array}{c}\text { Before } \\
\text { Treatment }\end{array} \\
\text { Initial } \\
\text { values }\end{array}$} & \multicolumn{2}{|c|}{$\begin{array}{c}\text { Microbial Consortium } \\
\text { Treatment }\end{array}$} & \multirow{2}{*}{$\begin{array}{c}\begin{array}{c}\text { Before } \\
\text { Treatment }\end{array} \\
\text { Initial } \\
\text { values }\end{array}$} & \multicolumn{2}{|c|}{$\begin{array}{c}\text { Microbial Consortium } \\
\text { Treatment }\end{array}$} \\
\hline & & & $\begin{array}{l}\text { Consortium } \\
\text { Group } 1\end{array}$ & $\begin{array}{l}\text { Consortium } \\
\text { Group } 2\end{array}$ & & $\begin{array}{l}\text { Consortium } \\
\text { Group } 1\end{array}$ & $\begin{array}{l}\text { Consortium } \\
\text { Group } 2\end{array}$ & & $\begin{array}{l}\text { Consortium } \\
\text { Group } 1\end{array}$ & $\begin{array}{c}\text { Consortium } \\
\text { Group } 2\end{array}$ \\
\hline $\begin{array}{l}\text { Hardness } \\
(\mathrm{mg} / \mathrm{l})\end{array}$ & $\begin{array}{l}\text { Not } \\
\text { objectionable }\end{array}$ & 325.125 & 28.4 & 14.3 & 86.5 & 50 & 36.5 & 56.7 & 33.3 & 50.1 \\
\hline $\mathrm{COD}(\mathrm{mg} / \mathrm{l})$ & $400 \mathrm{mg} / \mathrm{l}$ & $<1819.13$ & 10.4 & 51 & 56.5 & 29.7 & 47.8 & 458 & 33.4 & 72.5 \\
\hline TS $(\mathrm{g} / \mathrm{l})$ & $50 \mathrm{mg} / \mathrm{l}$ & 33.53 & 50.6 & 24.3 & 89.3 & 26.1 & 48.2 & 73.1 & 24.6 & 54.7 \\
\hline TSS (g/l) & $3000 \mathrm{mg} / \mathrm{l}$ & $<12.1$ & 59.2 & 15.4 & 26.2 & 32.1 & 23 & 84.6 & 45.5 & 69.4 \\
\hline TDS & $3000 \mathrm{mg} / \mathrm{l}$ & $<21.43$ & 50.2 & 25.6 & 66.4 & 25.1 & 47.2 & 69 & 15.6 & 54.2 \\
\hline $\mathrm{pH}$ & 5 to 9 & 10.5 & 7.3 & 5.1 & 9.3 & 2.1 & 0.7 & 13.6 & 7.8 & 11.4 \\
\hline Colour & Nil & 1.096 & 1.8 & 22.3 & 52.9 & 2.1 & 12.5 & 66.5 & 1.2 & 6.5 \\
\hline Turbidity & $\begin{array}{l}\text { Not } \\
\text { objectionable }\end{array}$ & 65.4 & 5.4 & 17.3 & 39 & 10.2 & 6.6 & 45.3 & 16.5 & 5.5 \\
\hline
\end{tabular}

Table 3. Percentage of Heavy metal concentration after Microbial Consortium treatment In Auto Mobile Industrial Waste Water

\begin{tabular}{|c|c|c|c|c|c|c|c|c|}
\hline \multirow[t]{2}{*}{ Test } & \multirow[t]{2}{*}{ Parameters } & \multirow{2}{*}{$\begin{array}{c}\text { Day 0 } \\
\text { (Before } \\
\text { Treatment) }\end{array}$} & \multicolumn{3}{|c|}{ Consortium Group 1} & \multicolumn{3}{|c|}{ Consortium Group 2} \\
\hline & & & Day 10 & Day 20 & Day 30 & Day 10 & Day 20 & Day 30 \\
\hline 1 & $\mathrm{PH}$ & $6.90 @ 25^{\circ} \mathrm{C}$ & $7.39 @ 25^{\circ} \mathrm{C}$ & 8.06@25ㄷ & 7.59@250C & 8.03@250C & 8.04@250C & 7.64@250C \\
\hline 2 & $\begin{array}{l}\text { Sulphate as } \\
\mathrm{SO}_{4}\end{array}$ & $577.35 \mathrm{mg} / \mathrm{l}$ & $34.58 \%$ & $29.22 \%$ & $25.51 \%$ & $33.73 \%$ & $27.08 \%$ & $22.05 \%$ \\
\hline 3 & Chloride as cl & $869.73 \mathrm{mg} / \mathrm{l}$ & $89.10 \%$ & $64.37 \%$ & $54.60 \%$ & $90.80 \%$ & $80.45 \%$ & $68.97 \%$ \\
\hline 4 & $\begin{array}{l}\text { Chemical } \\
\text { oxygen } \\
\text { demand }\end{array}$ & $490 \mathrm{mg} / \mathrm{l}$ & $32.65 \%$ & $24.49 \%$ & $20.41 \%$ & $51.43 \%$ & $22.86 \%$ & $17.96 \%$ \\
\hline 5 & Arsenic as As & $0.32 \mathrm{mg} / \mathrm{l}$ & BDL $(<0.05)$ & BDL $(<0.05)$ & BDL $(<0.05)$ & $81.26 \%$ & BDL $(<0.05)$ & BDL $(<0.05)$ \\
\hline 6 & $\begin{array}{l}\text { Cadmium as } \\
\text { cd }\end{array}$ & $3.2 \mathrm{mg} / \mathrm{l}$ & BDL $(<0.05)$ & BDL $(<0.05)$ & BDL $(<0.05)$ & BDL $(<0.05)$ & BDL $(<0.05)$ & BDL $(<0.05)$ \\
\hline 7 & Copper as cu & $22 \mathrm{mg} / \mathrm{l}$ & $2.55 \%$ & $1.86 \%$ & $0.64 \%$ & $1.95 \%$ & $0.36 \%$ & $0.27 \%$ \\
\hline 8 & $\begin{array}{l}\text { Hexavalent } \\
\text { chromium }\end{array}$ & $0.08 \mathrm{mg} / \mathrm{l}$ & BDL $(<0.05)$ & BDL $(<0.05)$ & BDL $(<0.05)$ & BDL $(<0.05)$ & BDL $(<0.05)$ & BDL $(<0.05)$ \\
\hline 9 & Lead as pb & $17.02 \mathrm{mg} / \mathrm{l}$ & BDL $(<0.05)$ & BDL $(<0.05)$ & BDL $(<0.05)$ & $87.37 \%$ & BDL $(<0.05)$ & BDL $(<0.05)$ \\
\hline 10 & Mercury as Hg & $0.06 \mathrm{mg} / \mathrm{l}$ & BDL $(<0.05)$ & BDL $(<0.05)$ & BDL $(<0.05)$ & BDL $(<0.05)$ & BDL $(<0.05)$ & BDL $(<0.05)$ \\
\hline 11 & Nickel as $\mathrm{Ni}$ & $0.54 \mathrm{mg} / \mathrm{l}$ & $72.22 \%$ & $22.22 \%$ & $20.37 \%$ & $31.48 \%$ & BDL $(<0.05)$ & BDL $(<0.05)$ \\
\hline 12 & $\begin{array}{l}\text { Selenium as } \\
\text { Se }\end{array}$ & $2.7 \mathrm{mg} / \mathrm{l}$ & BDL $(<0.05)$ & BDL $(<0.05)$ & BDL $(<0.05)$ & BDL $(<0.05)$ & BDL $(<0.05)$ & BDL $(<0.05)$ \\
\hline 13 & Zinc as Zn & $0.74 \mathrm{mg} / \mathrm{l}$ & $97.29 \%$ & $20.27 \%$ & BDL $(<0.05)$ & $87.83 \%$ & $55.40 \%$ & $48.64 \%$ \\
\hline
\end{tabular}

BDL: Below Detectable limits [DL-0.05]

Table 4. Percentage of Heavy metal concentration after Microbial Consortium treatment In Food Industrial Waste Water

\begin{tabular}{|c|c|c|c|c|c|c|c|c|}
\hline \multirow[t]{2}{*}{ Test } & \multirow[t]{2}{*}{ Parameters } & \multirow{2}{*}{$\begin{array}{c}\text { Day 0 } \\
\text { (Before } \\
\text { Treatment) }\end{array}$} & \multicolumn{3}{|c|}{ Consortium Group 1} & \multicolumn{3}{|c|}{ Consortium Group 2} \\
\hline & & & Day 10 & Day 20 & Day 30 & Day 10 & Day 20 & Day 30 \\
\hline 1 & $\mathrm{PH}^{\mathrm{H}}$ & $6.70 @ 25 \mathrm{C}$ & 7.39@2500 & 8.03@250C & $8.64 @ 25^{\circ} \mathrm{C}$ & $7.35 @ 25^{\circ} \mathrm{C}$ & $7.85 @ 25^{\circ} \mathrm{C}$ & $6.94 @ 25^{\circ} \mathrm{C}$ \\
\hline 2 & Sulphate as $\mathrm{SO}_{4}$ & $292.84 \mathrm{mg} / \mathrm{l}$ & $76.10 \%$ & $67.48 \%$ & $44.64 \%$ & $69.06 \%$ & $64.45 \%$ & $28.33 \%$ \\
\hline 3 & Chloride as cl & $1444 \mathrm{mg} / \mathrm{l}$ & $76.15 \%$ & $39.80 \%$ & $30.11 \%$ & $72.69 \%$ & $45.87 \%$ & $31.15 \%$ \\
\hline 4 & Chemical oxygen demand & $22400 \mathrm{mg} / \mathrm{l}$ & $71.42 \%$ & $19.64 \%$ & $14.28 \%$ & $98.66 \%$ & $53.57 \%$ & $23.66 \%$ \\
\hline 5 & Arsenic as As & $2.81 \mathrm{mg} / \mathrm{l}$ & BDL $(<0.05)$ & BDL $(<0.05)$ & $45.55 \%$ & BDL $(<0.05)$ & BDL $(<0.05)$ & BDL $(<0.05)$ \\
\hline 6 & Cadmium as cd & $0.08 \mathrm{mg} / \mathrm{l}$ & BDL $(<0.05)$ & BDL $(<0.05)$ & BDL $(<0.05)$ & BDL $(<0.05)$ & BDL $(<0.05)$ & BDL $(<0.05)$ \\
\hline 7 & Copper as cu & $58 \mathrm{mg} / \mathrm{l}$ & $11.27 \%$ & $4.36 \%$ & $0.48 \%$ & $4.39 \%$ & $0.53 \%$ & $0.39 \%$ \\
\hline 8 & Hexavalent chromium & BDL $(<0.05)$ & BDL $(<0.05)$ & BDL $(<0.05)$ & BDL $(<0.05)$ & BDL $(<0.05)$ & BDL $(<0.05)$ & BDL $(<0.05)$ \\
\hline 9 & Lead as pb & $2.46 \mathrm{mg} / \mathrm{l}$ & BDL $(<0.05)$ & BDL $(<0.05)$ & BDL $(<0.05)$ & $71.95 \%$ & BDL $(<0.05)$ & BDL $(<0.05)$ \\
\hline 10 & Mercury as Hg & BDL $(<0.05)$ & BDL $(<0.05)$ & BDL $(<0.05)$ & BDL $(<0.05)$ & BDL $(<0.05)$ & BDL $(<0.05)$ & BDL $(<0.05)$ \\
\hline 11 & Nickel as $\mathrm{Ni}$ & $0.55 \mathrm{mg} / \mathrm{l}$ & $32.72 \%$ & $20 \%$ & $10.90 \%$ & $38.18 \%$ & $34.54 \%$ & $16.36 \%$ \\
\hline 12 & Selenium as Se & $1.23 \mathrm{mg} / \mathrm{l}$ & BDL $(<0.05)$ & BDL $(<0.05)$ & BDL $(<0.05)$ & BDL $(<0.05)$ & BDL $(<0.05)$ & BDL $(<0.05)$ \\
\hline 13 & Zinc as Zn & $0.98 \mathrm{mg} / \mathrm{l}$ & $7.14 \%$ & $46.93 \%$ & BDL $(<0.05)$ & $55.10 \%$ & $53.06 \%$ & $42.85 \%$ \\
\hline
\end{tabular}

BDL: Below Detectable limits [DL-0.05] 
Table 5. Percentage of Heavy metal concentration after Microbial Consortium treatment In Pharmaceutical Waste Water

\begin{tabular}{|c|c|c|c|c|c|c|c|c|}
\hline \multirow[t]{2}{*}{ Test } & \multirow[t]{2}{*}{ Parameters } & \multirow{2}{*}{$\begin{array}{c}\text { Day 0 } \\
\text { (Before } \\
\text { Treatment) }\end{array}$} & \multicolumn{3}{|c|}{ Consortium Group 1} & \multicolumn{3}{|c|}{ Consortium Group 2} \\
\hline & & & Day 10 & Day 20 & Day 30 & Day 10 & Day 20 & Day 30 \\
\hline 1 & $\mathrm{PH}^{\mathrm{H}}$ & $6.90 @ 25^{0} \mathrm{C}$ & 7.99@250C & 7.49@250C & 6.94@250C & 7.93@250C & $7.46 @ 25^{\circ} \mathrm{C}$ & $6.94 @ 25^{\circ} \mathrm{C}$ \\
\hline 2 & $\begin{array}{l}\text { Sulphate as } \\
\mathrm{SO}_{4}\end{array}$ & $368.26 \mathrm{mg} / \mathrm{l}$ & $86.01 \%$ & $25 \%$ & $22.53 \%$ & $83.25 \%$ & $25.43 \%$ & $17.47 \%$ \\
\hline 3 & $\begin{array}{l}\text { Chloride as } \\
\text { cl }\end{array}$ & $1749.45 \mathrm{mg} / \mathrm{l}$ & $82.54 \%$ & $67.71 \%$ & $62.28 \%$ & $95.99 \%$ & $61.12 \%$ & $55.12 \%$ \\
\hline 4 & $\begin{array}{l}\text { Chemical } \\
\text { oxygen } \\
\text { demand }\end{array}$ & $412 \mathrm{mg} / \mathrm{l}$ & $96.17 \%$ & $85.43 \%$ & $50.48 \%$ & $89.62 \%$ & $62.65 \%$ & $46.60 \%$ \\
\hline 5 & $\begin{array}{l}\text { Arsenic as } \\
\text { As }\end{array}$ & $0.07 \mathrm{mg} / \mathrm{l}$ & BDL $(<0.05)$ & BDL $(<0.05)$ & BDL $(<0.05)$ & BDL $(<0.05)$ & BDL $(<0.05)$ & $\begin{array}{c}\text { BDL } \\
(<0.05)\end{array}$ \\
\hline 6 & $\begin{array}{l}\text { Cadmium as } \\
\text { cd }\end{array}$ & $1.2 \mathrm{mg} / \mathrm{l}$ & BDL $(<0.05)$ & BDL $(<0.05)$ & BDL $(<0.05)$ & BDL $(<0.05)$ & BDL $(<0.05)$ & $\begin{array}{c}\text { BDL } \\
(<0.05)\end{array}$ \\
\hline 7 & Copper as cu & $1.16 \mathrm{mg} / \mathrm{l}$ & $57.75 \%$ & $47.41 \%$ & BDL $(<0.05)$ & $84.48 \%$ & $9.48 \%$ & $5.17 \%$ \\
\hline 8 & $\begin{array}{l}\text { Hexavalent } \\
\text { chromium }\end{array}$ & $0.84 \mathrm{mg} / \mathrm{l}$ & BDL $(<0.05)$ & BDL $(<0.05)$ & BDL $(<0.05)$ & BDL $(<0.05)$ & BDL $(<0.05)$ & $\begin{array}{c}\text { BDL } \\
(<0.05)\end{array}$ \\
\hline 9 & Lead as pb & $0.09 \mathrm{mg} / \mathrm{l}$ & BDL $(<0.05)$ & BDL $(<0.05)$ & BDL $(<0.05)$ & BDL $(<0.05)$ & BDL $(<0.05)$ & $\begin{array}{c}\text { BDL } \\
(<0.05)\end{array}$ \\
\hline 10 & $\begin{array}{l}\text { Mercury as } \\
\mathrm{Hg}\end{array}$ & $0.65 \mathrm{mg} / \mathrm{l}$ & BDL $(<0.05)$ & BDL $(<0.05)$ & BDL $(<0.05)$ & BDL $(<0.05)$ & BDL $(<0.05)$ & $\begin{array}{c}\text { BDL } \\
(<0.05)\end{array}$ \\
\hline 11 & Nickel as $\mathrm{Ni}$ & $7.21 \mathrm{mg} / \mathrm{l}$ & $5.13 \%$ & $2.63 \%$ & BDL $(<0.05)$ & $3.32 \%$ & BDL $(<0.05)$ & $\begin{array}{c}\text { BDL } \\
(<0.05)\end{array}$ \\
\hline 12 & $\begin{array}{l}\text { Selenium as } \\
\text { Se }\end{array}$ & $0.08 \mathrm{mg} / \mathrm{l}$ & BDL $(<0.05)$ & BDL $(<0.05)$ & BDL $(<0.05)$ & BDL $(<0.05)$ & BDL $(<0.05)$ & $\begin{array}{c}\text { BDL } \\
(<0.05)\end{array}$ \\
\hline 13 & Zinc as Zn & $1.52 \mathrm{mg} / \mathrm{l}$ & $38.81 \%$ & $25 \%$ & $11.18 \%$ & $42.76 \%$ & $34.21 \%$ & $11.84 \%$ \\
\hline
\end{tabular}

BDL: Below Detectable limits [DL-0.05]

Based on the morphological, physiological, biochemical characteristics of the strain is close to the members of genus Pseudomonadales, Enterobacterales and Bacillales. The partially amplified for five different samples correspondingly $1245 \mathrm{bp}, 1266 \mathrm{bp}, 980 \mathrm{bp}, 840 \mathrm{bp}$ and $908 \mathrm{bp}$ fragment of $16 \mathrm{~S}$ rDNA sequence was submitted to NCBI database search using Blastn to confirm the species of the bacterium. The highest sequence similarity revealed that it is closely related to Acinetobacter pittii accession number MH496640, Escherichia coli accession number MH496639, Fictibacillus nanhaiensis accession number MH496638, Lysinibacillus xylanilyticus accession number MH496636 and Planococcus maritimus accession number MH496637.
The multiple sequence alignment and the phylogenetic relationship confirmed the highest sequence similarity with Acinetobacter pittii (MH071327.1) with distribution of the top 155 blast hits, Escherichia coli (CP028589.1) with distribution of the top 200 blast hits, Fictibacillus nanhaiensis (KY082742.1) with distribution of the top 106 blast hits, Lysinibacillus xylanilyticus (MH496636.1) with distribution of the top 200 blast hits and Planococcus maritimus (KR063196.1) with distribution of the top 108 blast hits on 100 subject sequences (Figure 1 to 5). 


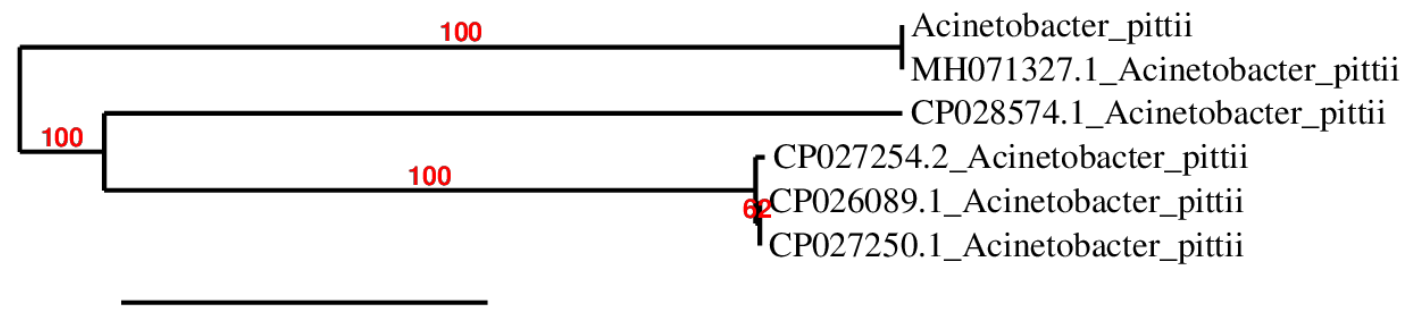

0.2

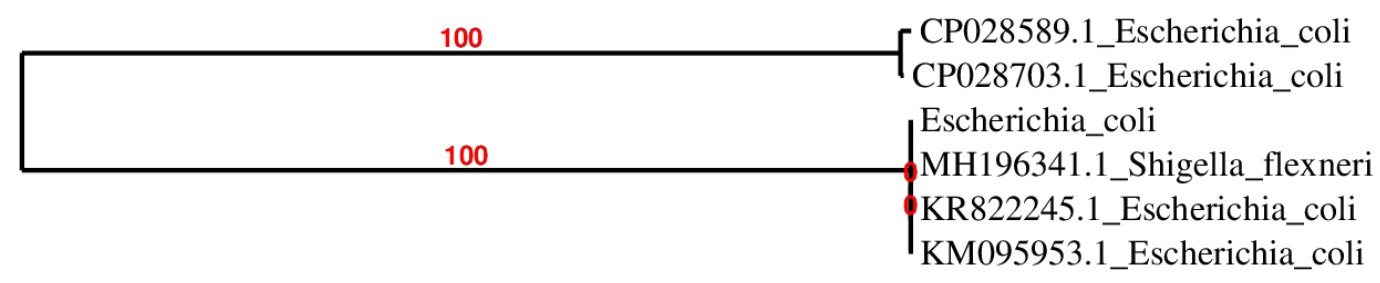

0.3

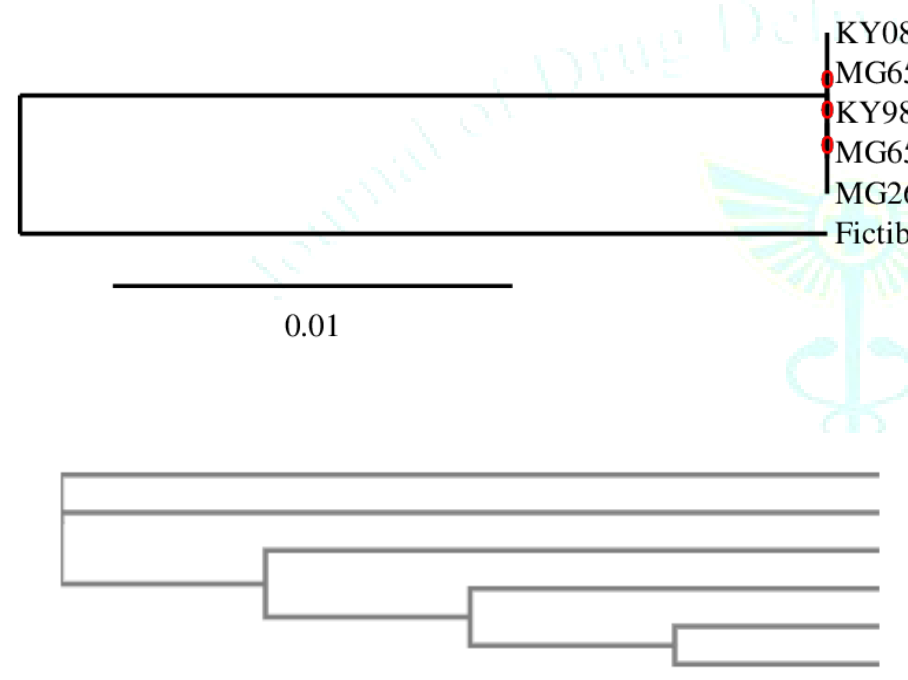

Lysinibacillus xylanilyticus

MH496636.1_Lysinibacillus_xylanilyticus

MF138115.1_Lysinibacillus xylanilvticus

MH542661.1_Lysinibacillus_macroides

AB547221.1_Lysinibacillus_fusiformis

MH718361.1_Lysinibacillus_fusiformis

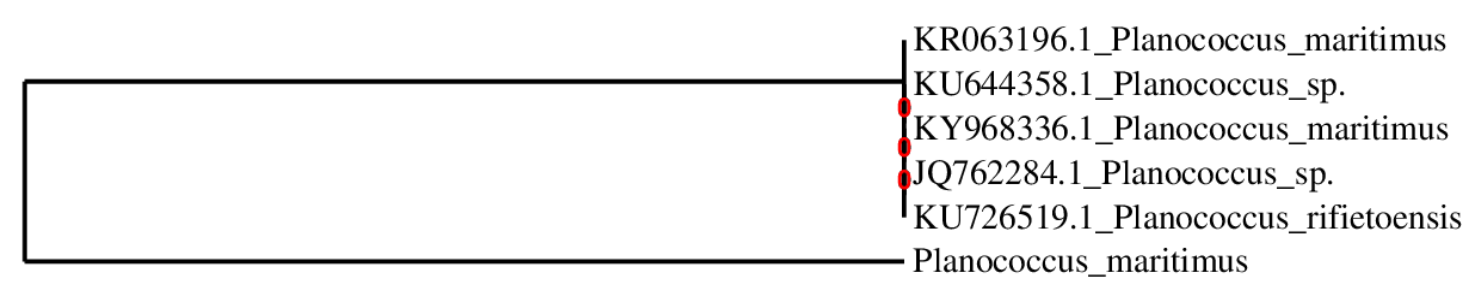

0.005

Figure 1to 5: Phylogenetic relationship based on 16S rDNA sequence comparison showing the position of Acinetobacter pittii (MH496640), Escherichia coli (MH496639), Fictibacillus nanhaiensis (MH496638), Lysinibacillus xylanilyticus (MH496636) and Planococcus maritimus (MH496637). The GeneBank accession numbers for the 16S rDNA sequences are given after the strain in parenthesis. while scale bar corresponds to nucleotide sequence difference.

The calculation and classification of phylogenetic relationship was determined and PhyML was shown to be atleast as accurate as other existing phylogeny programs using simulated data, while being one order of magnitude faster. The program Tree Dyn 198.3 was used for tree rendering. 


\section{CONCLUSION:}

To conclude that the present study revealed that the bacterial isolates were able to tolerate of the discussed different concentration of heavy metals recovered from the contaminated sites. Furthermore, the isolates were resistant to the different antibiotics which were used against the isolates. Thus, the present study justify that heavy metal resistance leads to antibiotic resistance, also these bacterial isolates can be used for the bioremediation of heavy metals. Microbial cultures are the only method that can eliminate the waste problem in economic way. This ecological approach will lead to economically and environmentally safe waste water treatment system and reducing the burden of waste water management.

\section{REFERENCES:}

1. Hussein, H. 2004. Biosorption of heavy metals from waste water using Pseudomonas sp, Electron. J. Biotechnol. 1, 38-46.

2. Masood, F., \& Malik. A. 2011. Biosorption of metal ions from aqueous solution and tannery effluent by Bacillus sp. $J$. Environ. Sci. Health. 46, 1667-1674.

3. Nies, D.H. and Silver, S. 1995. Ion efflux systems involved in bacterial metal resistances, J. Ind. Microbiol. 14, 189-199.

4. Blake, R. C. 1993. Chemical transformation of toxic metals by a Pseudomonas strain from a toxic waste site. Environ. Toxicol. Chem. 12, 1365-1376.

5. Silver, S. and Phung, L. T. 1996. Bacterial heavy metal resistances: new surprises. Rev. Microbiol. 50, 753-789.

6. Blake, R. C. 1993. Chemical transformation of toxic metals by a Pseudomonas strain from a toxic waste site. Environ. Toxicol. Chem. 12, 1365-1376.

7. Murali, O. and Mehara, S. 2014. Bioremediation of heavy metals using Spirulina. Int. J. Geol. 4, 244-249.

8. Green-Ruiz, C. 2008. Cadmium and zinc removal from aqueous solutions by Bacillus jeotgali: $\mathrm{pH}$, salinity and temperature effects. Biores. Technol. 99, 3864-3870.
9. Norton, L. 2004. Biosorption of zinc from aqueous solutions using biosolids. Adv. Env. Res. 8, 629-635.

10. Viera, R. H. S. F. \& Volesky, B. 2000. Biosorption: a solution to pollution? Int. Microbiol. 3, 17-24.

11. Gupta, V. K. \& Rastogi, A. 2008. Biosorption of lead from aqueous solutions by green algae Spirogyra species: kinetics and equilibrium studies. J. Hazard. Mater. 152, 407-414.

12. Mahilarasi A, Jaianand K, Balaji P, Veeramanikandan V. 2019. Development and Use of Microbial Consortium for Treatment of Different Types of Industrial Waste Water. Journal of Emerging Technologies and Innovative Research. 6(04): 332337.

13. Mahilarasi A, Veeramanikandan V, Jaianand K, Balaji P. 2018. Isolation, Characterization and Identification of Bacteria from Hosur Industrial area and their Tolerance to Antibiotics and Heavy Metals. International Journal of Scientific Research in Science and Technology. 4(10): 82-89.

14. APHA, 1995. In: Standard methods for the examination of the water and waste water. American Public Health Association, New York.

15. Bureau of Indian Standards (BIS). 2005. Specification of drinking water. IS: 10500 , Bureau of Indian Standards. New Delhi.

16. Dereeper A, Guignon V, Blanc G, Audic S, Buffet, Gascuel O. 2008. Phylogeny.fr: robust phylogenetic analysis for the nonspecialist. Nucleic Acids Res.1:36.

17. Edgar, R. C. 2004. MUSCLE: multiple sequence alignment with high accuracy and high throughput. Nucleic. Acids. Res. 32(5), 1792-1797.

18. Talavera, G.; Castresana, J. 2007. Improvement of phylogenies after removing divergent and ambiguously aligned blocks from protein sequence alignments. Syst. Biol. 56, 564-577.

19. Edwards U, Rogall T, Blocker H, Emde M, Bottger EC. 1989. Isolation and direct complete nucleotide determination of entire genes: characterization of a gene coding for16S ribosomal RNA. Nucleic Acids Res 17: 7843-7853. 